\title{
PENINGKATAN TEACHER ENGAGEMENT MELALUI PENGUATAN KEPEMIMPINAN OTENTIK DAN KESEIMBANGAN KEHIDUPAN KERJA
}

\author{
Dian Ary Kusumah $^{a)}$, Nandang Hidayat ${ }^{b)}$, Sri Setyaningsih ${ }^{\left.b^{*}\right)}$ \\ a) SMA Negeri Kota Bogor, Jawab Barat \\ ${ }^{b)}$ Universitas Pakuan, Bogor, Indonesia \\ *)e-mail korespondensi: : sri_setya@unpak.ac.id
}

riwayat artikel : diterima: 06 November 2020; direvisi: 16 November 2020; disetujui: 06 Desember 2020

\begin{abstract}
Abstrak. Penelitian ini bertujuan untuk mengetahui secara empirik peningkatan Teacher Engagement melalui Kepemimpinan Otentik dan keseimbangan kehidupan kerja Guru Tetap Yayasan (GTY) SMK Swasta se-Kecamatan Tanah Sareal Kota Bogor. Jumlah sampel penelitian sebanyak 136 guru yang diambil dari 206 guru tetap yayasan, secara acak dengan menggunakan tekhnik proportional random sampling. Metode yang digunakan adalah metode korelasional. Pengujian hipotesis yang dilakukan dengan menggunakan analisis statistic parametric dalam bentuk analisis regresi linier sederhana dan berganda, analisis korelasi sederhana dan berganda serta analisis parsial pada taraf signifikansi $\alpha=0,01$ dan $\alpha=0,05$. Penelitian ini menghasilkan tiga kesimpulan. Petama, terdapat hubungan positif dan signifikan antara Kepemimpinan Otentik (X1) dengan Teacher Engagement $(Y)$ yang ditunjukan dengan persamaan regresi linear sederhana $\hat{\mathrm{Y}}=31,05+0,76 \mathrm{X} 1$ dengan koefisien korelasi ry1 $=0,892$, koefisien determinasi Ry12 0,7050, signifikansi korelasi sebesar 22,89. Kedua, terdapat hubungan positif dan signifikan antar keseimbangan kehidupan kerja (X2) dengan Teacher Engagement $(Y)$ yang ditunjukan dengan persamaan regresi linear $\hat{Y}=28,14+0,78 X 2$. dengan koefisien korelasi ry2 $=0,75$, koefisien determinasi ry $22=0,6514$ dan signifikansi korelasi 13,21. Ketiga, terdapat hubungan positif dan signifikan antara Kepemimpinan otentik otentik dan keseimbangan kehidupan kerja secara bersama-sama dengan Teacher Engagement yang ditunjukkan dengan persamaan $\hat{Y}=$ $26,05+0,56 \mathrm{X} 1+0,24 \mathrm{X} 2$, koefisien korelasi ry. $12=0,715$, koefisien determinasi ry. $122=0,715$ dan signifikansi korelasi sebesar 20,43. Berdasarkan hasil penelitian akhir, maka dapat dinyatakan bahwa Teacher Engagement GTY SMK Swasta sekecamatan Tanah Sareal Kota Bogor dapat ditingkatkan melalui Kepemimpinan Otentik dan Keseimbangan kehidupan Kerja.
\end{abstract}

Kata Kunci: kepemimpinan otentik; keseimbangan kehidupan kerja; teacher engagement

\section{ENHANCING TEACHER ENGAGEMENT THROUGH STRENGTHENING AUTHENTIC LEADERSHIP AND WORK- LIFE BALANCE}

\begin{abstract}
The purpose of this study was to determine empirically the improvement of teacher engagement through Authentic Leadership and The Work-Life Balance of Private Vocational School Teacher Foundation (GTY) in Tanah Sareal District, Bogor City. The number of research samples was 136 teachers who were taken from 206 permanent teachers from the school foundation. It was taken randomly by using proportional random sampling technique. The method was the correlation method. Hypothesis testing was using parametric statistical analysis in the form of simple and multiple linear regression analysis, simple and multiple correlation analysis as well as partial analysis at the significance level $\alpha=0.01$ and $\alpha=0.05$. This research brought three conclusions. Firstly, there was a positive and significant relationship between Authentic Leadership (X1) and Teacher Engagement $(Y)$ which was shown by a simple linear regression equation $\hat{Y}=31.05+0.76 X 1$ with a correlation coefficient ryl $=0.892$, the coefficient of determination Ry12 0.7050, significance a correlation of 22.89. Secondly, there was a positive and significant relationship between work-life balance $(X 2)$ and Teacher Engagement $(Y)$ which was shown by the linear regression equation $\hat{Y}=28.14+0.78 X 2$. with a correlation coefficient of ry $2=0.75$, the coefficient of determination ry $2=$ 0.6514 and a correlation significance of 13.21. Thirdly, there was a positive and significant relationship between authentic authentic leadership and work-life balance together with teacher engagement as indicated by the equation $\hat{Y}=26.05+0.56 X 1$ $+0.24 X 2$, the correlation coefficient ry. $12=0.715$, the coefficient of determination ry. $122=0.715$ and the significance of the correlation was 20.43. Based on the results of the final research, it is stated that the GTY teacher engagement of private vocational schools in Tanah Sareal Sub-district-Bogor City can be strengthened by Authentic Leadership and Work-Life Balance.
\end{abstract}

Keywords: authentic leadership, work-life balance, teacher engagement

\section{PENDAHULUAN}

Pendidikan merupakan bagian yang tidak dapat terpisahkan dari kehidupan kita sebagai manusia. Suatu usaha yang dapat meningkatkan kualitas kehidupan manusia seumur hidupnya adalah proses pendidikan. Sumber daya manusia merupakan hal yang paling penting dibandingkan sumber daya lainnya dalam proses pendidikan di sekolah. Sumber daya 
manusia memiliki peran utama dalam memanfaatkan sumber daya lain secara optimal untuk mencapai tujuan sekolah melalui pelaksanaan visi dan misi sekolah. Keterikatan dan keterlibatan sumber daya manusia sebagai seseorang yang memiliki peran penting di organisasi diharapkan berdampak positif untuk organisasinya. Guru sebagai sumber daya manusia di sekolah adalah kunci utama dalam sistem pendidikan, dalam dunia pendidikan khususnya sekolah, pendidikan tidak banyak berarti apabila fungsi dasar pembelajaran yaitu interaksi guru dengan peserta didik tidak berkualitas. Demikian pentingnya peran guru sehingga dapat disimpulkan bahwa peningkatan kualitas dan kinerja guru akan sangat berpengaruh terhadap kualitas/mutu pendidikan. Selain dari itu sudah menjadi suatu kewajiban guru harus dapat difungsikan sebagai teladan yang mampu melahirkan generasi muda yang memiliki karakter yang merujuk pada moralitas, integritas serta loyalitas.

Salah satu konsep yang muncul sebagai upaya pengembangan dari konsep-konsep sebelumnya seperti kepuasan kerja karyawan, komitmen karyawan, serta perilaku organisasi karyawan adalah employee engagement. Teacher Engagement (Guru yang engages) akan bersedia dengan senang hati melakukan tugas-tugasnya dengan seluruh kemampuannya bahkan bersedia untuk bekerja diluar jam kerja jika diperlukan. Mereka cenderung akan menetap di organisasi dan selalu berusaha bekerja untuk meningkatkan hal positif untuk organisasinya. Hal ini berbeda dengan guru yang disengages, mereka hanya akan bersedia bekerja diluar tugas jika diberikan imbalan yang menurut mereka sesuai dan mereka akan sering mengeluh apabila menganggap pekerjaan ataupun imbalan tidak sesuai. Teacher engagement telah muncul sebagai salah satu tantangan besar di sekolah saat ini. Dengan kompleksitas dan peraturan yang ketat di banyak sekolah, teacher engagement akan terus menantang manajemen sekolah, karena keterlibatan dan keterikatan adalah elemen penting dalam menjaga vitalitas, kelangsungan hidup, dan profitabilitas sekolah. Sekolah yang memiliki guru yang sangat terikat dan terlibat memiliki keuntungan lebih besar daripada yang tidak. Sekolah dengan guru yang sangat terikat dan terlibat mengalami peningkatan kepuasan pelanggan, keuntungan, dan produktivitas sekolah.

Penelitian ini bertujuan menemukan upaya-upaya untuk meningkatkan teacher engagement guru, melalui analisa tentang hubungan antara variabel teacher engagement dengan kepemimpinan otentik, hubungan antara peningkatan teacher engagement dengan keseimbangan kehidupan kerja dan hubungan antara peningkatan teacher engagement dengan kepemimpinan otentik dan keseimbangan kehidupan kerja secara bersama-sama serta menemukan upaya untuk mengatasi permasalahan peningkatkan teacher engagement melalui kepemimpinan otentik dan keseimbangan kehidupan kerja.

\section{Teacher Engagement}

Engagement adalah keadaan abadi yang digambarkan secara psikologis hadir dalam peran seseorang yang bekerja (Kahn, 1992). Kehadirannya memiliki empat dimensi: perhatian, keterhubungan, integrasi, dan fokus pada pertunjukan peran. Melalui atmosfer kepercayaan dan keamanan, engagement bisa berkembang. Individu yang memiliki engages sangat tinggi dengan tugas-tugas mereka, akan menjadi lebih efisien dan karena itu lebih cenderung untuk mengambil lebih banyak tanggung jawab (Christian, Garza, \& Slaughter, 2011: 89-136). Perasaan positif dan rasa antusias yang tinggi seseorang terhadap pekerjaan dapat disebut dengan employee engagement. Seseorang yang memiliki engagement tinggi cenderung memiliki kinerja yang lebih baik karena memiliki perasaan yang positif dan tidak menjadikan pekerjaannya sebagai beban. Penelitian telah menemukan hubungan positif antara employee engagement dan kinerja organisasi. Perusahaan dengan karyawan yang engaged memiliki retensi yang tinggi, hasil dari menurunnya turn over karyawan, mengurangi niat untuk keluar dari perusahaan, meningkatkan produktivitas, profitabilitas, pertumbuhan dan kepuasan pelanggan (Muliawan, Perizade, 2017: 69-78).

Pihak manajemen organisasi harus focus untuk mengembangkan dan memelihara engagement antara karyawan dengan perusahaan, yang menumbuhkan hubungan dua arah antara pihak manajemen dan karyawan (Markos \& Sridevi, 2010: 89-96). Bahwa karyawan yang merasakan dukungan organisasi yang lebih kuat, lebih memungkinkan untuk membalasnya dengan tingkatan engagement yang lebih kuat pula dalam bekerja dan otomatis kepada organisasinya. Karenanya, engagement adalah kemitraan antara organisasi dan individu (Wolf, Ward, \& Kinzie,2009: 152-153), yang berkonotasi kepada pentingnya memahami organisasi, dan seluruh individu dalam organisasi ketika engagement tersebut dipelajari (Picard, Karalyn, Kutsyuruba, 2017: 89-100).

Berdasarkan hasil kajian teori diatas, maka disintesiskan teacher engagement adalah keterikatan dan keterlibatan yang kuat dari guru untuk berkontribusi lebih pada komitmen emosional sekolah, tujuan sekolah, dan perkembangan sekolah. Indikator teacher engagement adalah: 1) kesungguhan dalam bekerja, 2) kegigihan guru dalam bekerja, 3) pengorbanan guru untuk organisasi, 4) antusiasme guru terhadap organisasi dan 5) kolaborasi dengan rekan sejawat.

\section{Kepemimpinan Otentik}

Kepemimpinan didefinisikan sebagai tindakan memengaruhi yang dilakukan pemimpin agar tercapai esuksesan dalam Organisasi (Patras, Hidayat 2019: 91). Kepemimpinan kepala sekolah adalah kemampuan yang menentukan terciptanya kualitas proses belajar mengajar untuk mempengaruhi para guru dan personil sekolah yang lain dalam rangka mencapai tujuan-tujuan sekolah (Komariah, 2014: 194-200). Meskipun kepala sekolah memiliki tanggung jawab dan akuntabilitas masing-masing, mereka tidak dapat diharapkan untuk menangani tantangan saat ini sendirian Penelitian longitudinal McLaughlin tahun 1995 tentang perbedaan antara sekolah yang berprestasi rendah dan teratas menemukan bahwa sekolah yang sukses memiliki komunitas guru pembelajar. Keberhasilan sekolah datang tidak hanya melalui perubahan struktural, tetapi juga sama pentingnya, budaya profesional yang mencakup fokus pada siswa dan pembelajaran mereka, dukungan untuk ide-ide baru dan inovatif, dan dialog serta kekuatan bersama staf (MacTavish \& Kolb, 2006: 211- 
220). Menurut Chaidir (2013: 71-75), banyak faktor yang menjadi penggerak atau driver reputasi internal organisasi, salah satunya yaitu kepemimpinan otentik dengan komunikasi yang transparan dalam organisasi. Pemimpin yang otentik memiliki pemahaman akan tujuan. Mereka mengetahui siapakah diri mereka dan arah yang mereka tuju. Selain mengetahui tujuannya, pemimpin yang otentik diinspirasi dan secara intrinsik dimotivasi oleh tujuan mereka. Mereka adalah individu yang antusias dan memiliki minat mendalam terhadap apa yang mereka lakukan dan benar-benar peduli dengan pekerjaan mereka (Pardede \& Mayasari, 2014:89-95).

Berdasarkan hasil kajian teori di atas dapat disintesiskan bahwa kepemimpinan otentik adalah perilaku memimpin seorang kepala sekolah yang menekankan pada proses membangun legitimasi pemimpin kepada timnya melalui hubungan yang jujur dan menghargai masukan dari bawahan, yang dibangun di atas landasan moral dan memiliki kesejalanan antara perilaku dan keyakinan. Indikator kepemimpinan otentik dalam penelitian ini adalah: (1) keterbukaan/transparansi relasional, (2) kepercayaan diri dalam memimpin, (3) penggunaan perspektif moral, (4) saling percaya dalam menjalankan tugas, (5) penerapan kebijakan yang konsisten.

\section{Keseimbangan Kehidupan Kerja}

Konflik yang berbenturan antara pekerjaan (work) dan kehidupan pribadi (life) dapat meningkatkan level stress pegawai yang pada akhirnya dapat memicu menurunnya moral pegawai, produktivitas yang rendah dan penurunan kepuasan pegawai terhadap pekerjaan dan organisasi tempatnya bekerja. Penerapan work-life balance (keseimbangan kehidupan kerja) mempengaruhi efektivitas, efisiensi dan kualitas pelayanan dengan tanggung jawab pegawai dirasa perlu oleh banyak organisasi. Fungsi, tugas, tanggung jawab serta akuntabilitas pegawai harus diperjelas karena mereka adalah kunci dalam kualitas pelayanan. Demikian pula pengetahuan dan keterampilan mereka yang harus terus-menerus ditingkatkan. Semakin baik penerapan konsep keseimbangan kehidupan kerja maka semakin baik pula efektifitas suatu organisasi (Risna, Ambo Sakka, 2017:1-8).

Menurut Frame dan Hartog dalam Moedy (2013: 211-220) work-life balance berarti karyawan dapat dengan bebas menggunakan jam kerja yang fleksibel untuk menyeimbangkan pekerjaan atau karyanya dengan komitmen lain seperti keluarga, hobi, seni, studi dan tidak hanya focus fokus terhadap pekerjaannya. Kemudian menurut Moore dalam Moedy (2013:106-108) work- life balance yang baik didefinisikan sebagai situasi dimana pekerja merasa mampu menyeimbangkan pekerjaan dan kehidupan pribadi atau komitmen lain (Ganapathi, 2016:125-135). Tidak hanya perusahaan saja yang diharapkan untuk membuat kebijakan keseimbangan kehidupan kerja, akan tetapi karyawan seharusnya juga dapat menyeimbangkan perannya dan bekerja secara profesional agar keseimbangan kerja dapat terealisasi dengan baik (Musadieq, 2018:9-17). Berdasarkan hasil kajian teori mengenai keseimbangan kehidupan kerja disintesiskan keseimbangan kehidupan kerja adalah kondisi seorang guru dalam keadaan seimbang antara peran dalam pekerjaannya dengan kehidupan pribadinya yang dijalani dengan komitmen tinggi. Indikator keseimbangan kehidupan kerja dalam penelitian ini adalah: (1) penempatan prioritas antara pekerjaan dan kehidupan diluar pekerjaan, (2) pengaturan jam kerja yang fleksibel, (3) peningkatan kualitas pribadi, (4) komitmen yang tinggi kepada keluarga, pekerjaan dan hal lain, (5) peningkatan produktivitas kerja.

\section{METODE PENELITIAN}

Penelitian ini merupakan penelitian kuantitatif dengan menggunakan metode survei dengan teknik korelasional dan analisis SITOREM (Scientific Identification Theory to Conduct Operation Research in Education Management). Dengan 2 variabel bebas yaitu kepemimpinan Otentik (X1), keseimbangan kehidupan kerja (X2), dan satu variabel terikat Teacher engagement (Y). Penelitian ini menggunakan sampel Guru Tetap Yayasan SMK Swasta se-Kecamatan Tanah Sareal Kota Bogor dengan jumlah populasi sebanyak 206 orang. Dalam penentuan jumlah sampel penelitian ini mengunakan rumus Slovin. diperoleh jumlah sampel 136 orang. Pengambilan sampel dari tiap-tiap sekolah dengan proportional random sampling yaitu pengambilan sampel yang memperhatikan pertimbangan unsur-unsur atau kategori dalam populasi penelitian (Arikunto, 2006). Metode pengumpulan data menggunakan metode angket, dengan menyebarkan instrument kuesioner melalui daring (menggunakan google form) kepada responden dikarenakan sedang dalam masa pandemi COVID 19.

\section{HASIL DAN PEMBAHASAN}

\section{Pengujian Persyaratan Analisis \\ 1. Uji Normalitas}

Berdasarkan hasil perhitungan uji normalitas galat baku taksiran $(\mathrm{Y}-\hat{\mathrm{Y}} 1)$ variabel Teacher engagemenet $(\mathrm{Y})$ terhadap variabel Kepemimpinan otentik (X1) diperoleh nilai Lhitung sebesar 0,076 yang lebih kecil dari nilai Ltabel, pada taraf signifikansi 0,05, dengan demikian dapat disimpulkan bahwa galat baku taksiran Teacher engagement atas variabel Kepemimpinan otentik berasal dari populasi yang berdistribusinormal. Perhitungan uji

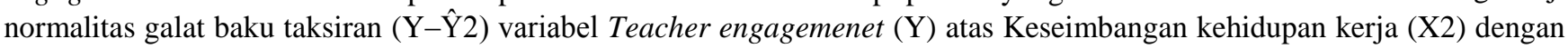
Ltabel sebesar 0,076 menghasilkan nilai Lhitung sebesar 0,0754. Karena nilai Lhitung< Ltabel, pada taraf signifikansi 0,05, maka dapat disimpulkan bahwa galat baku taksiran Teacher engagement atas variabel Kepemimpinan otentik juga berasal 
dari populasi berdistribusi normal.

\section{Uji Homogenitas}

Pengujian homogenitas varians (ragam) kelompok data variabel teacher engagement atas variabel kepemimpinan otentik diuji dengan persyaratan kelompok data homogen dengan menggunakan uji Bartlett. Persyaratan data homogen adalah bila nilai 2 hitung $<$ nilai $\chi 2$ tabel pada taraf signifikansi $\alpha=0,05$. Dari hasil perhitungan uji homogenitas variabel variabel Teacher engagement $(\mathrm{Y})$ atas variabel Kepemimpinan otentik(X1) diperoleh nilai $\chi 2$ hitung sebesar 49,750 sedangkan $\chi 2$ tabelpada taraf signifikansi $\alpha=0,05$ adalah 52,192. Dengan demikian dapat disimpulkan bahwa kelompok data Teacher engagemenet $(Y)$ atas variabel Kepemimpinan otentik (XI) berasal dari populasi yang homogen. Perhitungan uji homogenitas variabel Teacher engagement atas variabel Keseimbangan kehidupan kerja menghasilkan nilai $\chi 2$ hitungsebesar 35,834 sedangkan $\chi 2$ tabel pada $\alpha=0,05$ adalah 47,400. Karena nilai $\chi^{2}<\chi^{2}$, maka dapat disimpulkan bahwa kelompok data Teacher engagemenet $(\mathrm{Y})$ atas variabel Keseimbangan kehidupan kerja $(\mathrm{X} 2)$ berasal dari populasi yang homogen.

\section{Pengujian Hipotesis}

1. Hubungan antara kepemimpinan otentik dengan Teacher engagement

Berdasarkan hasil uji signifikansi ditemukan bahwa harga keberartian regresi : Fhitung $=346,949$ lebih besar dari Ftabel $=3,91$ pada taraf signifikansi $\alpha=0.05$, yang berarti regresi $\hat{Y}=31,048+0,7618$ X1adalah signifikan, dapat dipergunakan sebagai acuan untuk memprediksi, menjelaskan serta mendapatkan kesimpulan hubungan antara variabel kepemimpina otentik dengan Teacher engagement. Berdasarkan perhitungan uji signifikansi, maka diperoleh Hubungan dinyatakan signifikan apabila nilai Fhitung lebih besar dari nilai Ftabel, pada taraf signifikansi $\alpha=0,05$ sedangkan persamaan regresi dikatakan linier apabila nilai Fhitung lebih kecil dari nilai Ftabel. Berdasarkan hasil pengujian terhadap hipotesis pertama, ditemukan bahwa terdapat hubungan positif yang signifikan antara variabel kepemimpinan otentik dengan variabel teacher engagement. Artinya, semakin tinggi kepemimpinan otentik, maka semakin tinggi pula teacher engagement. Sebaliknya semakin rendah kepemimpinan otentik maka semakin rendah pula teacher engagement yang dimiliki oleh GTY SMK Swasta se- Kecamatan Tanah Sareal Kota Bogor.

\section{Hubungan antara Keseimbangan Kehidupan Kerja dengan Teacher Engagement}

Berdasarkan hasil pengujian terhadap hipotesis kedua maka ditemukan terdapat hubungan positif yang signifikan antara variabel keseimbangan kehidupan kerja dengan variabel teacher engagement. Artinya, semakin tinggi keseimbangan kehidupan kerja maka semakin tinggi pula teacher engagement. Sebaliknya semakin rendah keseimbangan kehidupan kerja, maka semakin rendah pula teacher engagementyang diperlihatkan GTY SMK Swasta se-Kecamatan Tanah Sareal Kota Bogor.

\section{Hubungan antara Kepemimpinan Otentik dan Keseimbangan kehidupan Kerja secara bersama-sama dengan Variabel Teacher Engagement.}

Berdasarkan hasil pengujian terhadap hoptesis ketiga maka terdapat hubungan positif yang signifikan antara variabel kepemimpinan otentik dan keseimbangan kehidupan kerja secara bersama-sama dengan teacher engagement, yamg artinya semakin tinggi kepemimpinan otentik dan keseimbangan kehidupan kerja maka semakin tinggi pula teacher engagement. Sebaliknya semakin rendah kepemimpinan otentik dan keseimbangan kehidupan kerja, maka 90 semakin rendah pula teacher engagement yang diperlihatkan GTY SMK Swasta se-Kecamatan Tanah Sareal Kota Bogor.

\section{Korelasi Parsial}

Hasil analisis korelasi parsial hubungan antara variabel kepemmpinan otentik dengan teacher engagement dengan kontrol keseimbangan kehidupan kerja menghasilkan koefisien korelasi parsial sebesar 0,49. Sedangkan signifikasnsi korelasi parsial dengan menggunakan uji t menghailkan thitung sebesar 2,79. Pada taraf signifikansi $\alpha=0,05$ maka diperoleh ttabel sebesar 1,97. Hasil ini memenuhi kriteria siginifikasnsi yaitu thitung> ttabel sehingga dapat disimpukan bahwa korelasi parsial variabel kepemmpinan otentik dengan teacher engagement dengan kontrol keseimbangan kehidupan kerjaja adalah signifikan. Hasil analisis korelasi parsial hubungan antara variabel keseimbangan kehidupan kerja dengan teacher engagement dengan kontrol kepemimpinan otentik menghasilkan koefisien korelasi parsial sebesar 0.07 . Sedangkan signifikansi korelasi parsial dengan menggunakan uji t menghasilkan thitung sebesar 10,00. Pada taraf signifikansi $\alpha=0,05$ maka diperoleh ttabel sebesar 1,97. Hasil ini memenuhi kriteria siginifikasnsi yaitu t hitung $>$ ttabel sehingga dapat disimpukan bahwa korelasi parsial variabel keseimbangan kehidupan kerja dengan teacher engagement dengan kontrol kepemimpinan otentik adalah signifikan.

\section{Pembahasan}

\section{Hubungan antara Kepemimpinan Otentik (X1) dengan Teacher Engagement (Y)}

Hasil penelitian menunjukkan bahwa terdapat hubungan positif antara Kepemimpinan Otentik (X1) dengan teacher engagement $(\mathrm{Y})$. Hal ini ditunjukkan oleh koefisien korelasi ry $1=0,794$ dengan koefisien determinasi r $2 \mathrm{y} .1=0,630$. Hal ini berarti bahwa Kepemimpinan Otentik memberi kontribusi sebesar 68,80\% terhadap teacher engagement, sedangkan 31,20\% teacher Engagement dipengaruhi oleh faktorlain. Hasil penelitian ini menyimpulkan bahwa kepemimpinan otentik yang 
dimiliki memberikan kontribusi positif yang berpengaruh nyata terhadap teacher engagement. Penelitian ini mendukung penelitian Firdaus et. al (2018:288-295) yang berjudul Pengaruh Kepemimpinan Otentik Terhadap Work Engagement Melalui Psychological Capital, menyimpulkan terdapat hubungan positif yang signifikan antara kepemimpinan otentik pada variabel psychological capital. Adanya pengaruh positif yang diberikan kepemimpinan otentik dan psychological capital pada variabel work engagement. Hasil analisis penelitian menunjukkan jika nilai r-square sebesar 0,613 berarti bahwa pengaruh kepemimpinan otentik terhadap work engagement sebanyak $61,3 \%$ dan sisanya sebanyak $38,7 \%$ merupakan pengaruh dari faktor yang lain. Pengaruh kepemimpinan otentik terhadap work engagement mempunyai nilai $\mathrm{t}$ statistik diatas 1,96 dengan nilai original sampel sebesar 0,292 (bertanda positif) sehingga hipotesis kedua dapat diterima yaitu kepemimpinan autentik berpengaruh signifikan positif terhadap work engagement.

\section{Hubungan antara Keseimbangan Kehidupan Kerja (X2) dengan Teacher Engagement (Y)}

Hasil penelitian menunjukkan bahwa terdapat hubungan positif antara Keseimbangan Kehidupan Kerja dengan Teacher Engagement. Hal ini ditunjukkan oleh koefisien korelasi (ry.2) sebesar 0,703 yang dinyatakan sangat signifikan. Kontribusi Keseimbangan Kehidupan Kerja terhadap Teacher Engagement sebesar 70,30\% yang dinyatakan dengan nilai koefisien determinasi (r2y.1) sebesar 0,174. Koefisien korelasi parsial Teacher Engagement (dengan variabel Keseimbangan Kehidupan Kerja dikendalikan) adalah sebesar 0,703 yang dinyatakan sangatsignifikan.

Penelitianini mendukung peneliti sebelumnya, Risna (2017:1-8). Pengaruh Work-life balance (Keseimbangan Kehidupan Kerja) Terhadap Kepuasan Kerja Perawat Pada Tenaga Kerja Perawat, Di Badan Layanan Umum Daerah (BLUD) Rumah Sakit Konawe Selatan Tahun 2016. Menyimpulkan terdapat pengaruh Work-life balance (Keseimbangan Kehidupan Kerja) Terhadap Kepuasan Kerja Perawat Pada Tenaga Kerja Perawat secara signifikan. Keseimbangan keterlibatan ada pengaruh secara secara signifikan terhadap kepuasan kerja perawat. Hal ini disebabkan oleh adanya kebiasan dari para perawat yang mampu bertanggung jawab terhadap terhadap perkerjaan, dapat bertangggung jawab antara keluarga dan pekerjaan, setia terhadap rumah sakit tempat bekerja dan mau berkomitmen untuk keluarga. di BLUD Rumah Sakit Konawe Selatan tahun 2016. Hasil uji statistik Chi-Square pada taraf kepercayaan 95\% $(0,05)$ menunjukkan bahwa $\rho$ Value $=0,014$, artinya bahwa ada pengaruh yang signifikan antara keseimbangan keterlibatan terhadap kepuasan kerja perawat di BLUD Rumah Sakit Konawe Selatan tahun 2016.

Meskipun hasil koefisien korelasi pada penelitian ini berbeda, namun semuanya memberikan kesimpulan yang sama yaitu bahwa terdapat hubungan positif yang signifikan antara Keseimbangan Kehidupan KerjadenganTeacherEngagement

\section{Hubungan antara Kepemimpinan Otentik (X1) dan Keseimbangan Kehidupan Kerja (X2) Secara bersama-sama dengan Teacher Engagement ( $\mathrm{Y})$}

Hubungan yang signifikan kedua variabel ini mengindikasikan bahwa, adanya pengaruh Kepemimpinan Otentik (X1) dan Keseimbangan Kehidupan Kerja (X2) secara bersama-sama terhadap Teacher Engagement (Y) SMK Swasta seKecamatan Tanah Sareal Kota Bogor. Berdasarkan pembahasan hasil penelitian di atas, dapat disimpulkan bahwa terdapat hubungan positif yang signifikan dengan kekuatan hubungan yang kuat antara variabel Kepemimpinan Otentik dan Keseimbangan Kehidupan Kerja secara bersama-sama dengan variabel Teacher Engagement yang bermakna, semakin tinggi tingkat variabel Kepemimpinan Otentik dan Keseimbangan Kehidupan Kerja secara bersama-sama, maka semakin tinggi pula Teacher Engagementakan diperlihatkan oleh Guru Tetap Yayasan SMK Swasta Se-Kecamatan Tanah Sareal Kota Bogor.

Dengan bertolak dari penilaian seorang pakar (expert judgement) dan analisis peneliti, maka dapat disususn bobot ururtan prioritas indikator- indikator yang perlu segera diperbaiki dan indikator-indikator yang tetap dipertahankan atau dikembangkan. Rakapitulasi hasil akhir analisis SITOREM dapat dilihat pada tabel berikut ini:

Tabel 1. Analisis SITOREM

\begin{tabular}{lll}
\hline \multicolumn{1}{c}{ Indicator in Initial State } & Indicator after weighting by expert & Indicator Value \\
\hline Kesungguhan dalam bekerja, & $1^{\text {st }}$ Kesungguhan dalam bekerja (24\%) & 3,65 \\
\hline Kegigihan guru dalam bekerja, & $2^{\text {nd }}$ Kolaborasi dengan rekan sejawat (24\%) & 3.65 \\
\hline Pengorbanan guru untuk organisasi, & $3^{\text {rd }}$ Antusiasme guru terhadap organisasi (18\%) & 3,77 \\
\hline Antusiasme guru terhadap organisasi & $4^{\text {th }}$ Kegigihan guru dalam bekerja (18\%) & 3,39 \\
\hline Kolaborasi dengan rekan sejawat. & $5^{\text {th } \text { Pengorbanan guru untuk organisasi (16\%) }}$ & 3,02 \\
\hline
\end{tabular}




\begin{tabular}{|c|c|c|}
\hline \multicolumn{3}{|c|}{ Kepemimpinan Otentik } \\
\hline Indicator in Initial State & Indicator after weighting by expert & Indicator Value \\
\hline Keterbukaan/transparansi relasional, & $1^{\text {st }}$ Kepercayaan diri dalam memimpin $(24 \%)$ & 4,04 \\
\hline Kepercayaan diri dalam memimpin, & $2^{\text {nd }}$ Penerapan kebijakan yang konsisten $(23 \%)$ & 4.08 \\
\hline $\begin{array}{l}\text { Penggunaan perspektif moral, yang } \\
\text { konsisten. }\end{array}$ & $3^{\text {rd }}$ Keterbukaan/transparansi relasional $(18 \%)$ & 3,28 \\
\hline $\begin{array}{l}\text { Saling percaya dalam menjalankan } \\
\text { tugas, }\end{array}$ & $\begin{array}{l}4^{\text {th }} \text { Saling percaya dalam menjalankan } \\
\text { tugas }(18 \%)\end{array}$ & 4,04 \\
\hline Penerapan kebijakan & $5^{\text {th }}$ Penggunaan perspektif moral $(10 \%)$ & 3,15 \\
\hline \multicolumn{3}{|c|}{ Keseimbangan Kehidupan Kerja } \\
\hline Indicator in Initial State & Indicator after weighting by expert & Indicator Value \\
\hline $\begin{array}{l}\text { Penempatan prioritas antara } \\
\text { pekerjaan dan kehidupan diluar } \\
\text { pekerjaan, }\end{array}$ & $1^{\text {st }}$ Peningkatan kualitas pribadi $(23 \%)$ & 4,48 \\
\hline Pengaturan jam kerja yang fleksibel, & $\begin{array}{l}2^{\text {nd }} \text { Pengaturan jam kerja yang fleksibel } \\
(22 \%)\end{array}$ & 4.48 \\
\hline Peningkatan kualitas pribadi, & $\begin{array}{l}3^{\text {rd }} \text { Komitmen yang tinggi kepada } \\
\text { keluarga, pekerjaan dan hal lain }(18 \%)\end{array}$ & 3,97 \\
\hline $\begin{array}{l}\text { Komitmen yang tinggi kepada } \\
\text { keluarga, pekerjaan dan hal lain, }\end{array}$ & $4^{\text {th }}$ Peningkatan produktivitas kerja $(18 \%)$ & 4,49 \\
\hline Peningkatan produktivitas kerja. & $\begin{array}{l}5^{\text {th }} \text { Penempatan prioritas antara } \\
\text { pekerjaan dan kehidupan diluar } \\
\text { pekerjaan }(18 \%)\end{array}$ & 4,37 \\
\hline
\end{tabular}

\section{Prioritas indikator dipertahankan Prioritas indikator ditingkatkan}

$1^{\text {st }}$ Peningkatan produktivitas kerja $2^{\text {nd }}$ Pengaturan jam kerja yang fleksibel

$3^{\text {rd }}$ Penerapan kebijakan yang konsisten $4^{\text {th }}$ Penempatan dalam prioritas hidup $5^{\text {th }}$ Penerapan kebijakan yang konsisten $6^{\text {th }}$ Kepercayaan diri dalam memimpin $7^{\text {th }}$ Saling percaya dalam menjalankan tugas $1^{\text {st }}$ Komitmen yang tinggi kepada keluarga, pekerjaan dan hal lain

$2^{\text {nd }}$ Antusiasme guru terhadap organisasi

$3^{\text {rd }}$ Kolaborasi dengan rekan sejawat

$4^{\text {th }}$ Kesungguhan dalam bekerja

$5^{\text {th }}$ Kegigihan guru dalam bekerja

$6^{\text {th }}$ Keterbukaan/transparansi relasional

$7^{\text {th }}$ Penggunaan perspektif moral

$8^{\text {th }}$ Pengorbanan guru untuk organisasi

\section{SIMPULAN}

Berdasarkan hasil penelitian, disimpulkan bahwa teacher engagement dapat ditingkatkan melalui variabel kepemimpinan otentik dan keseimbangan kehidupan kerja, baik secara terpisah maupun bersama-sama. Ditemukan terdapat hubungan positif yang sangat signifikan dengan kekuatan hubungan yang moderate antara variabel kepemimpinan otentik dengan teacher engagement, terdapat hubungan positif yang sangat signifikan dengan kekuatan hubungan yang kuat antara variabel keseimbangan kehidupan kerja dengan teacher engagement, dan terdapat hubungan positif yang sangat signifikan dengan kekuatan hubungan yang kuat antara variabel kepemimpinan otentik dan keseimbangan kehidupan kerja secara bersama-sama dengan teacher engagement. 


\section{REFERENSI}

Christian, M. S., Garza, A. S., \& Slaughter, J. E. (2011). Work engagement: A quantitative review and test of its relations with task and contextual performance. Personnel Psychology, 64(1), 89-136. https://doi.org/10.1111/j.1744$\underline{6570.2010 .01203 . x}$

Firdaus, A. (2018). Pengaruh Kepemimpinan Autentik Terhadap Work Engagement Melalui Psychological Capital Sebagai Variabel Intervening (Studi Pada Karyawan Bagian Kantor PT. Perkebunan Nusantara X Pabrik Gula Lestari Di Nganjuk). Jurnal Ilmu Manajemen (JIM), 6(3), 288-295.

Ganapathi, I. M. D. (2016). Pengaruh Work Life Balance Terhadap Kepuasan Kerja Karyawan (Studi pada PT. Bio Farma Persero). Fakultas Komunikasi Dan Bisnis, Universitas Telkom, IV(1), 125-135. Retrieved from http://www.researchgate.net/publication

Komariah, A. (2014). Authentic Leadership Kepala Sekolah Dalam. Administrasi Pendidikan, VIII(229), $194-200$.

MacTavish, M., \& Kolb, J. (2006). Encouraging Teacher Engagement: A New Approach to Performance Improvement in Schools. Online Submission.

Markos, S., \& Sridevi, M. S. (2010). Employee Engagement: The Key to Improving Performance. International Journal of Business and Management, 5(12), 89-96.

Musadieq, M. Al. (2018). Pengaruh Work-Life Balance Terhadap Kepuasan Kerja (Studi Pada Karyawan Perempuan Yayasan Insan Permata Tunggulwulung Kota Malang). Jurnal Administrasi Bisnis, 60(1), 9-17.

Patras, Hidayat. (2019). Pengaruh Kepemimpinan, Keadilan, dan Kepercayaan pada Keterlibatan Kinerja Dosen. Manajeria, Jurnal Manajemen Pendidikan Islam- 4,1, 85-101.

Picard, Karalyn, Kutsyuruba, B. (2017). Teachers' Engagement in Professional Development: A Collective Case Study. Journal of Educational Policies and Current Practices, 2(2), 89-100.

Risna, Ambo Sakka, I. Y. (2017). Pengaruh Work-life balance (Keseimbangan Kehidupan Kerja) Terhadap Kepuasan Kerja Perawat Pada Tenaga Kerja Peraway Di Badan Layanan Umum Daerah (BLUD) Rumah Sakit Konawe Selatan Tahun 2016. Jurnal Ilmiah Mahasiswa Kesehatan Masyarakat, 2(250), 1-8.

Pardede, P. P., \& Mayasari, M. (2014). Kepemimpinan Otentik dan Komunikasi yang Transparan dari Segi Persepsi Karyawan, (2004). 